IZA DP No. 4480

The Gender Gap in Early Career in Mongolia

Francesco Pastore

October 2009

Forschungsinstitut zur Zukunft der Arbeit Institute for the Study of Labor 


\title{
The Gender Gap in Early Career in Mongolia
}

\author{
Francesco Pastore \\ Seconda Università di Napoli \\ and IZA
}

Discussion Paper No. 4480

October 2009

\author{
IZA \\ P.O. Box 7240 \\ 53072 Bonn \\ Germany \\ Phone: +49-228-3894-0 \\ Fax: +49-228-3894-180 \\ E-mail: iza@iza.org
}

Any opinions expressed here are those of the author(s) and not those of IZA. Research published in this series may include views on policy, but the institute itself takes no institutional policy positions.

The Institute for the Study of Labor (IZA) in Bonn is a local and virtual international research center and a place of communication between science, politics and business. IZA is an independent nonprofit organization supported by Deutsche Post Foundation. The center is associated with the University of Bonn and offers a stimulating research environment through its international network, workshops and conferences, data service, project support, research visits and doctoral program. IZA engages in (i) original and internationally competitive research in all fields of labor economics, (ii) development of policy concepts, and (iii) dissemination of research results and concepts to the interested public.

IZA Discussion Papers often represent preliminary work and are circulated to encourage discussion. Citation of such a paper should account for its provisional character. A revised version may be available directly from the author. 


\section{ABSTRACT}

\section{The Gender Gap in Early Career in Mongolia*}

Relatively little is known about the youth labour market in general and about gender differences in Mongolia, one of the fifty poorest countries in the world. This paper addresses the issue by taking advantage of a School to Work Survey (SWTS) on young people aged 15-29 years carried out in 2006. On average, female wages are not lower than those of males. However, women have a much higher average educational level than men: in fact, although not statistically significant among teenagers (15-19), the conditional gender gap becomes significant and sizeable for the over-20. The Juhn, Murphy and Pierce (1993) decomposition confirms that, if wages were paid equally, women should have $11.7 \%$ more considering only their educational advantage and overall $22 \%$ more, a substantial gap for the low earnings of Mongolians.

JEL Classification: I21, J13, J24, J31, J62, P30, R23

Keywords: school-to-work transitions, earnings equations, decomposition analysis, gender wage gap, Asia, Mongolia

Corresponding author:

Francesco Pastore

Seconda Università di Napoli

Faculty of Law

Via Mazzocchi, 5

81055 - Santa Maria Capua Vetere (CE)

Italy

E-mail: fpastore@unina.it

\footnotetext{
* This paper elaborates on findings of research work carried out as part of the project "Promoting decent and productive work for young women and men in Mongolia" within the framework of the ILO/Korea Partnership programme, which have circulated in the ILO Employment Working Paper no. 14. Special thanks are due to all those who have carried out the Mongolian SWTS. The author wishes to thank also Claire Harasty, Diego Rei as well as two referees for useful comments on an earlier version. The usual disclaimer applies.
} 


\section{Introduction}

Relatively little is known about the youth labour market in general and about gender differences, in particular, in Mongolia. Nonetheless, an increasing number of publications (see, for instance, UNDP, 2003; UNIFEM 2008; ODI, 2008) argue that gender equality is at the core of the Millennium Development Goals. In fact, it is explicitly mentioned in goal 3 (“promotion of gender equality and empowerment of women”) and 5 ("improvement in maternal health"), while being also implicit in all other goals and especially in number 1 (“eradication of extreme poverty and anger”) and also 7 (“ensuring environmental sustainability”). In a nutshell, the reason why the promotion of women and of gender equality is at the core of any strategy to fight poverty and foster economic development is that in all developing countries women are a central part of any production process. In addition, with reference to goal 7, they are also responsible for household food production and consumption and account for a large and growing proportion of agricultural workers. In a changing development context, including globalisation and climate change, the links between women’s empowerment, natural resource management and food security are vital, yet often overlooked.

Furthermore, it should be also stressed that the position of women is different from one country to the other and that one should not think that the promotion of gender equality can be based on the same policy strategy everywhere. This implies that country-level studies are an important pre-condition for fine-tuning equality policy and implementing the millennium development goals.

This paper addresses the issues now posited by studying gender equality at the labour market among young (aged 15-29 years) Mongolians by taking advantage of an ad hoc School-to-Work Transition Survey (SWTS) carried out in 2006. Elaborations based on the SWTS show that there are important differences in the way young women and men understand their participation to the educational system and to the labour market in the case of Mongolia. Differences emerge already at school. In fact, young women have an advantage in terms of higher educational levels, of better employment prospects and lower risk of unemployment, but when unemployed remain so longer than men. In addition, women have roughly the same average hours of work than men, but a slightly greater chance of holding a contract. Finally, life aspirations are different, since girls wish to reach higher educational levels and give less importance to success in the labour market than men.

Overall, except for longer unemployment duration, women have an advantage in the labour market. Nonetheless, women might tend to self-select themselves into jobs that offer greater job stability, less commitment to work and provision of childcare allowances for lower pay. What do the data say? Unconditional female wages are not lower than those of males. However, this may potentially hide a discriminating behaviour against women, inasmuch as they have better productivity characteristics than men. In fact, the conditional gender gap is quite sizeable since, ceteris paribus, the median wage of women is about 25 per cent lower than that of men. The Juhn, Murphy and Pierce (1993, JMP) decomposition analysis confirms that if wages were paid equally, women should have $11.7 \%$ more, even if only considering their higher educational attainment. Taking into account all the different characteristics of men and women, it 
appears that women should have, on average, 22 per cent more, a substantial gap, considering the low earnings of Mongolians.

The structure of the paper is as follows. Section one gives brief background information on the macroeconomic framework in general and the youth labour market in particular. Section two summarises the main findings of a recent literature on the emergence of the gender gap in early career wages. Section three features the main labour market differences between young men and women in Mongolia. Section four quantifies the gender gap. Section five presents the results of JMP decomposition. Some summary remarks and policy implications follow.

\section{The Mongolian economy}

\subsection{The macroeconomic framework}

Mongolia is a large continental region sandwiched between Russia and China at the junction of the Siberian taiga forests, Dahurian steppes and Gobi Desert. On one hand, in urban areas, where aimag (provinces) and soum centres (rural districts) are located, economic transition has meant deep industrial restructuring and weakening of production. In Mongolia, economic transition from plan to market began in 1990, causing unprecedented problems, such as macroeconomic instability, the dismantling of the State sector and the need to encourage private initiative.

The manufacturing sector in particular experienced a dramatic process of downsizing and has only recently started expanding again, but still only represents a minor share of employment and, like the service sector, is mainly located in urban areas. The slowness of private sector growth has meant increased unemployment in urban areas and the need for many households to resort to agricultural activities in rural areas.

As Morris and Brunn (2005) noted, economic transition further increased a traditionally deep geographical divide between urban and rural areas in a country that is one of the largest and least densely populated in the world. On the other, in the almost untouched, vast and sometimes desert rural territories, the dismantling of State-owned and cooperative farms and the privatization of livestock has made herding often the only means of subsistence. A series of harsh winters and summer droughts resulted in many families losing their animals and moving to urban areas, thereby contributing to local unemployment there.

The new problems compound the old ones, especially poverty, making it harder for many families to survive. Comparison of Mongolia's ranking on the UNDP-based Human Development Index (HDI) and Human Poverty Index (HPI) seems to confirm this. In 2006, it ranked 116 on the former while only 42 on the latter, meaning it is one of the fifty poorest countries in the world. In addition, while the HDI ranking has improved in recent years, essentially due to a fast growth process, the HPI ranking has dropped further. Poverty and inequality, including gender inequality, represent important constraints for future development by hindering the expansion of internal demand, on one hand, and by reducing the competitiveness of the 
country in international markets, on the other, via a reduction of the educational and employment opportunities of the younger generation.

Solving the macroeconomic problems of the country by increasing the level of aggregate demand, boosting private sector growth and alleviating the hardship of the poorest households are important preconditions for young people and their families to support the cost of the transformation, become selfsustaining in the long term and, finally, generate a virtuous circle for economic growth and social development.

\subsection{Identikit of youth}

Mongolia has a young population with 55 per cent below the age of 25 years. The SWTS results show that on average young people marry early, 22 years for women and 23 years for men. The share of married people in the 15 to 29 age range is 34 per cent in rural areas and 18.2 per cent in urban areas. The relatively young age for marriage is typical of other socialist and developing countries and reflects the traditional model of household and gender roles. The share of divorce in the youth population is very low, at about 0.4 per cent.

For young people, families with more than one child are the norm. About 10 per cent of the youth population in the SWTS sample have a family with three children or more. A slightly higher share of women than men has three children or more because women marry earlier than men.

The one-breadwinner family model is the most common among the youth surveyed. Most women's spouses are employed, whereas most men's spouses are involved in unpaid family work or household duties. Around 62.2 per cent of male partners are in some form of remunerated activity. However, the remaining 37.8 per cent are unemployed, students or men involved in unpaid family work so that the wives are the breadwinners.

The 17 per cent of young people who are migrants confirms the nomadic nature of the population, especially those involved in herding. Not surprisingly, a large share of in-migrants, about 21.2 per cent, is in Ulaanbaatar, with a similar share in the aimag centres. In the soum centres, the percentage of in-migrants falls slightly to 16 per cent. In-migrants in rural areas are only about 8 per cent.

In the sample, the average monthly household income level is very low (TUGs123,580 i.e. about US\$106 and $€ 79$ ). In addition, there is a high level of inequality. Excluding the poorest (under the $10^{\text {th }}$ decile) and the richest (above the $90^{\text {th }}$ decile) households, the ratio of the richest to the poorest households' income is 6.7. At the time of the survey, the share of the population living on US\$30 a month or less was 10.1 per cent and those on US\$60 a month or less was 32.9 per cent. These shares are, however, lower than those reported by UNDP (2006, p. 293) based on average incomes for the period 1990-2004. This would suggest that an 
improvement has taken place in recent years. The poverty line, defined as the household income below half the median monthly household income is TUGs 50,000 (US\$43 or $€ 32)^{1}$.

\section{The state of the art}

Focusing on gender differences among young people in post-transition Mongolia, this paper is at the intersection of several strands of literature. The short overview contained in this section can only briefly summarise the main issues at stake.

The first strand has the evolution of gender differences at the labour market during transition from plan to market as its subject matter. Women have almost everywhere benefited of the emphasis of socialist times on equality of outcomes. This implies that surely the emergence of market forces has implied the loss of old privileges, but also the emergence of new opportunities, though such opportunities were not the same for every woman. According to Pastore and Verashchagina (2007), economic transition has generated different outcomes on female wages, with important cross-country differences. During transition, the conditional gender wage gap has remained constant in CEECs, due to greater labour market withdrawal of women, compared to FSU countries, where female wages decreased markedly, while their participation remained more stable. The stability of wages in CEECs has been reinforced by the selection of more skilled women into jobs. If only more skilled women remain employed, then average female wages might increase, not decrease, compared to men.

The second strand of literature regards the causes and consequences of gender differences in developing countries, highlighting different patterns across continents. Nonetheless, the 2000s have seen an increasing awareness that women are at the core of any strategy to fight poverty and promote economic growth as the discussion on the Millennium Development Goals has made clear (UNDP, 2003; UNIFEM 2008; ODI, 2008). In fact, gender equality is explicitly mentioned as one of the MDGs while remaining a pre-condition for achieving some of the others. Increasing the level of education of women, their share in wage employment and in national legislatures is the quickest way to increase the average productivity level of a country.

The third strand regards the issue of the emergence of gender differences in early career, when the females have not yet had children, creating a disadvantage in terms of lower work experience due to maternity leave and reduced motivation. The stylised facts that are at the core of any explanation of gender differences in early career are as follow: a) aspirations of women and men on labour market prospects are different already when they are at school or college; b) only for some specific categories of workers, the gender wage gap exists already at the time of labour market entry; c) however, typically it is low (or nonexistent) at young ages; d) but increases with time passing.

\footnotetext{
${ }^{1}$ As to the $31^{\text {st }}$ of May 2007, the nominal exchange rates of the TUG to the Euro and the US dollars were as follows: 1 Euro = 1566.8700 Tughrik; 1 Tughrik = 0.0006 Euro; 1 US Dollar = 1164.6993 Tughrik; 1 Tughrik = 0.0009 US Dollars.
} 
Different factors have been highlighted that affect female wages at different stages of a woman' career, from pre-market entry to retirement. First, as Filippin and Ichino (2005) show using a longitudinal data set of students at Bocconi University, women expect to be paid less than men already before labour market entry. Their expectations are also realistic as shown by comparison with realisations. Nonetheless, women tend to be more optimistic than justified by reality as to the length of the gender gap which is increasing with time, rather than reducing as they expect. Other studies suggest that women tend to choose different educational paths, curricula and fields of study consistently with their lower career expectations. Overall, this line of research suggests that women tend to self-select themselves into low wage and career jobs by lowering their expectations and choosing specific educational paths.

Second, Kunze $(2003$; 2005) has shown that in the case of skilled workers who have undertaken vocational training within the German dual system apprenticeship programme, a gender pay gap exists already at time of labour market entry and remains more or less constant over the years. She also recalls the findings of other studies reporting cases of entry wage gaps.

However, Manning and Swaffield (2008) show that in the UK the gender pay gap on entry to the labour market is almost zero, but ten years later it goes up to $25 \log$ points for women with children and to 12 points for women with no desire to establish a household yet. Pastore (2006) note that the pattern of evolution of the gender pay gap over time is in almost all EU countries the same as the one observed by Manning and Swaffield (2008) in the UK. In other words, the female to male pay ratio in terms of hourly wages is generally higher for adult than for young women. The difference is especially sizeable in some countries, such as Germany, Sweden, Finland and Denmark. Italy is an exception. There, in fact, young women experience a much lower female to male pay ratio (0.77) compared to their adult counterparts (0.85). Moreover, while the latter figure is roughly in line with that of other countries, the former is much lower than average.

The reason why women tend to accumulate an increasing pay gap compared to men over time is that they are forced to accumulate less work experience after giving birth. The extent to which their work experience is reduced by maternity is a function of a number of market conditions and policy tools, such as: a) the availability of jobs in the state sector and in big private companies where women rights are granted; b) the fiscal incentives and state financial support in favour of maternity; c) the availability of childcare facilities and especially kindergartens; d) the availability of part-time contracts that may help women reconcile work and family life; e) the low educational level of women who abandon the labour market after the birth of the first child.

The extreme paucity of basic forms of interventions in favour of women giving birth forces a large number of them to exit the labour market altogether, which is a possible explanation of the low participation rate of women. The low gender gap among adult people is to be explained by the fact that only the most motivated women remain at work. Motivation is shown in their refusing to establish a family and giving birth and/or choosing a job in sectors where maternity leave provisions are granted to women. 
This type of analysis shows the interrelation of female decisions regarding education and labour market participation. It also allows thinking of different policy tools, each able to help women at different stages of their career. Nonetheless, it should be also underlined that public policy aimed at helping women overcome their problems in childrearing at old ages might help them also to form aspirations that are more demanding in terms of career opportunities.

\section{Gender differences among young Mongolians}

The analysis is based on a SWTS on young people (15-29 years old) carried out in 2006 by the National Statistical Office of Mongolia with the International Labour Office's (ILO) financial and technical assistance. Being especially focused on young people, the SWTS has two main advantages: a) it contains more observations on the group of interest than available in any other sample survey run in the country; b) the questionnaire is especially designed to deal with the problems typical of this age group.

The survey is nationally representative of the underlying total sample population, covering 4585 households or about 0.75 percent of the total number of households in the country. In turn, this required including 154 primary sampling units for 6871 individuals.

The questionnaire includes information on family background, individual characteristics, including aspirations in life and in the labour market, household characteristics, employment status, recall data from the time of school, information on young people in-school and unemployed.

Table 1 shows that, in 2006, a low, but still noticeable share of 3.3 per cent of the population received no education. As is typical in other developing countries, in this share of "uneducated" young people there are twice as many men as women. As also noted in del Rosario (2005, p. 24), parents prefer to use boys rather than girls to herd. Based on answers to a question on the reasons for dropping out of school many women declare that they did so because it was their parents' choice and in many households, especially those in rural areas, female children are involved in domestic chores. The Table also shows that girls outperform boys in every field of education and at every age.

\section{[Table 1 about here]}

There are gender differences in employment opportunities as well. Table 2 gives the distribution of the youth population by labour market status. The female share of wage employment is similar to that of men, although many more men are self-employed than women are. The share of part-time work is extremely low for both genders. In emerging market economies that are in a condition of extreme poverty, part-time work is often seen as a loss of income, rather than an opportunity to better reconcile family and work duties. Parttime work is not a satisfactory option for firms either, for its high cost. In addition, as is typical of several developing and transition countries, many women prefer long maternity leave (up to three years) ${ }^{2}$.

\section{[Table 2 about here]}

\footnotetext{
${ }^{2}$ See, on this point, Malysheva and Verashchagina (2008).
} 
Figure 1 shows that the distribution of working hours is dispersed for both men and women. The peak is 40 hours per week, in line with labour agreements currently in place. However, the distribution is clearly multi-modal, with apparent peaks at 40, 55 and even 70 hours per week, with a high proportion of young people working extremely long hours. Men are more frequent among those with the heaviest workload. Among women, about 50 per cent work more than 40 hours and 33 per cent work more than 50 hours; among men, the comparable figures are 63 per cent and 45 per cent, respectively. Long working hours are typical of certain types of activity, such as pastures, which are very common among young people and where productivity is low.

\section{[Figure 1 about here]}

The most striking fact that Table 3 illustrates is the highest share, over 40 per cent, of young people employed in the livestock sector. The livestock, and more generally, the agricultural sector has further expanded since the start of transition and the ensuing fall in output experienced in urban areas, where the bite of reforms has been stronger (Morris and Brunn, 2005). More men than women work in the livestock sector. The opposite holds true for the other sectors, including manufacturing. In addition, herding is much more common among young teenagers and young adults. The reduction in the share of young people employed in the livestock sector by age might be suggestive of a tendency for them to use this type of employment as a temporary solution.

\section{[Table 3 about here]}

Informal work, here defined as working without a contract, is very common. Column 2 of Table 4 shows the percentage of informal work, while the other columns provide information on formal work and, in particular, on whether the work contract is written or oral, allowing a comparison of different degrees of formality. The information is broken down by age groups, gender and geographical location. About 60 per cent of the entire youth employment is informal. This is a very high share and confirms the poor employment prospects of young people. Unreported calculations show that informal work is evenly distributed across industrial sectors, but there are several important exceptions. Expectedly, it is much more common in the livestock sector, whereas it is almost absent in the State sector and less frequent in the manufacturing and mining sector. Most contracts that are held are only oral or temporary. Written contracts are more common among the oldest segment and oral contracts among young teenagers. Men work informally more frequently than women. Informal work is also more common in rural than in urban areas.

As shown in Table 2, women are more likely to be inactive. In fact, they are more frequently at school or engaged in the care of (younger or old) family members. Men have a higher unemployment to population ratio as compared to women, but the advantage of women almost vanishes when the unemployment rate is looked at: for women it is 28.9 per cent and for men it is 30 per cent. This is due to the higher inactivity rate of women compared to men. Moreover, the lower unemployment ratio for women being due to their staying at school longer, it disappears for the oldest segments of the sample.

Even if women have a lower unemployment to population ratio than men, the opposite is true of their periods of unemployment. The hypothesis is that women seek stable employment more frequently than men 
and are, therefore, less mobile in the labour market. If stable employment cannot be found, they prefer to wait, rather than going into the informal sector. Although temporary work is evenly distributed by gender, men accept informal work more frequently. Table 5 reports the distribution of unemployed youth by time to find a job, gender and age group. It shows that women experience longer unemployment spells than men.

\section{[Table 5 about here]}

Table 6 gives the distribution of long-term unemployment by gender for those young people who have children. It shows that the disadvantage of women in terms of the share of long-term and very long-term unemployment is much greater for women with children then men with children. As unemployed women with children are the larger number, this might be an important factor to explain the longer unemployment duration of women.

\section{[Table 6 about here]}

In unreported tabulations of answers to questions regarding the aspirations of young people by gender, it appears that differences are notable under some dimensions. The biggest difference is in the type of profession preferred, with typically women preferring office and professional jobs and men preferring manual and technical jobs. Also minor gender differences exist in terms of the three most important goals in life, with the share of those who give more importance to money and work success being greater among boys and the share of those who give more importance to building a family being greater among girls. Interestingly, these differences are particularly strong among young teenagers and tend to reduce with time passing. Finally, women tend to consider more important for success in the labour market reaching a high level of education and attaining a good knowledge of foreign languages, whereas boys consider more important to have good knowledge of information and communication technologies, of the business environment and having previous work experiences.

\section{Unconditional and conditional gender gap}

The previous section has shown that, except for longer unemployment duration, women have an advantage compared to men in terms of education attainment and also in terms of employment opportunities. The aim of this section is first of all to ascertain whether they are able to translate their advantage in higher wages and, if not, why this is the case.

The first immediate test of the existence of gender differences is the unconditional gap, namely the difference in wages between men and women. The unconditional does not take into account differences in productivity characteristics of men and women and the conditional (sometimes called adjusted or ceteris paribus) does. The unconditional gap can be obtained either dividing the (log) wage of women to that of men or by inserting a dummy for women in an earnings equation with only a constant term. A dummy for women in earnings equations augmented for all the observable variables available in the data measures the conditional gender wage gap. 
The conditional gender gap might be lower than the unconditional, if part of the average gap is due to the lower productivity of women due to, for example, less hours worked, lower human capital endowment, less work experience because of maternity leave, working in low productivity jobs and low pay sectors. On the contrary, when the conditional gender gap is greater than the unconditional, it means that women possess productivity characteristics to a greater extent than men, but are paid less.

Table 7 shows the unconditional gender wage gap, as obtained in wage equations including either only a dummy for gender or also human capital variables, proxies for educational levels and work experience. All the three age groups included in the data are considered. The expectation is that the gender wage gap should emerge among young adults as a consequence of the reduced work experience of women. In fact, it is important to recall from Section 1 that on average young people marry earlier than in mature market economies. Moreover, about 33 per cent of women and 21 per cent of men in the sample have children. Over 90 per cent of them have one or two children, but about 10 per cent have three children or more.

The unconditional gap is not statistically different from zero: on average, women and men have the same wages independent of their characteristics. Adding the (log of) hours of work to the estimates only slightly increases the gap, but the difference is still not significant from a statistical viewpoint. The only case when the hours worked are statistically significant is among young teenagers. The coefficient increases by age group, suggesting that similar to what happens in mature market economies, also in Mongolia, the disadvantage of women tends to increase with age.

It is only when adding controls for human capital variables that the gap becomes sizeable and statistical significant. Interestingly, it is statistically insignificant in the case of young teenagers, but reaches a high and constant level later on at the age when women tend to establish a family and to give birth. The gap in monthly wages $(-0.30)$ is slightly higher than that in hourly wages $(-0.23)^{3}$, also controlling for the hours worked in the former case.

\section{[Table 7 about here]}

The next step is to look at the impact of other variables on the gap. The equations in Table 8 report the determinants of net monthly wages. The log of the number of hours worked per week is used as an independent variable. The equations are augmented to consider a number of other characteristics, namely civil status, formal/informal employment, the status of migrant, union membership, past experiences of training, type of job search method adopted, industry and location. The coefficients of industry and location dummies are omitted for brevity's sake.

The statistical insignificance of working hours confirms a priori expectations that the hours actually worked do not affect young people’s earnings, independent of age and gender. The oldest segment is the only exception, though the coefficient is statistically significant only at the 10 per cent level.

\section{[Table 8 about here]}

${ }^{3}$ In case of independent dummy variables, the semi-elasticity interpretation is partly flawed and, following Halvorsen and Palmquist (1980), it should be computed as: $\left(e^{\beta}-1\right) * 100$. 
The wage effects of different educational qualifications are roughly comparable to those obtained by Darii and Suruga (2006), except for specialized secondary education. The results also suggest that young men with vocational education, especially men, have a very low wage premium compared to those with compulsory education or below. Generally speaking, except for the case of tertiary education, women exhibit higher returns to education than men, which is a typical finding in most countries (Psacharopoulos, 1994).

The survey distinguishes between no work experience, one through four years and more than five years of work experience. The estimated coefficient is generally statistically significant only for a work experience longer than four years. This effect is slightly higher for women.

Holding a fixed-term contract provides a higher gain for men, whereas a permanent contract for women. Men with a family obtain a wage gain with respect to singles, but this does not apply to women. Being a migrant causes a wage premium for women (when they migrated to study in another place) and a wage loss for men (when migrating with the family). Other individual characteristics do not significantly affect earnings.

The industry wage gap is sizeable, especially against workers involved in the livestock sector. Young people employed in any other sector, except fishery and, partly tourism, receive, ceteris paribus, higher wages. In addition, Ceteris paribus, the rural wage gap is especially sizeable for women (-73 per cent) compared to men (-28 per cent).

The augmented earnings equations suggest that the median wage of women is about 25 per cent lower than that of men with the same characteristics. ${ }^{4}$ Confirming a finding noted with reference to extended earnings equations, the gender dummy is statistically significant only for those who are older than 20 years. That the conditional is greater than the unconditional gap suggests that women have better productivity characteristics than men, but that such characteristics are paid less. This might be seen as prima facie evidence of some form of discrimination against women. Next section seeks evidence to confirm this expectation and asks the question of which characteristics are contributing more to the gap.

\section{Decomposing the gender gap}

The JMP decomposition analysis provides a method to test whether women have better or worse characteristics than men and whether they are paid differently. In fact, it allows distinguishing the impact on the gender gap of average differences in characteristics (Q, so-called quantity effect), differences in returns to those characteristics (P, so-called price effect) and of the residual wage distribution (U), which is unobserved. The price effects are due to different coefficients in Mincerian earnings equations. Differences in the residual distribution might capture the overall degree of wage inequality in the country and the way it affects the gender pay gap.

\footnotetext{
${ }^{4}$ Darii and Suruga (2006) found a coefficient of the gender dummy of -0.203 in a specification with only human capital and few other controls.
} 
Table 9 reports the results relative to Mongolia. As noted above, the unconditional gap is very small. However, differences in the other factors are significant. The analysis reveals a very interesting finding, namely that most of the gap is due to differences in the way the market values the same characteristics of men and women. Quantity effects tend to reduce the gap, whereas price effects tend to increase it. Women have better characteristics than men, captured by the fact that these differences favour women and, therefore, reduce the gap. A coefficient of -0.20 can be interpreted as saying that if they were paid in the same way, women would earn 20 per cent more, simply because they are potentially more productive and better educated.

However, when men and women have the same characteristics, a woman is paid less, as shown by the positive price effect. These differences increase the gap by about 23 per cent. The algebraic difference between this factor that increases the wage of men and the former factor that increases the wage of women is a wage difference in favour of men of about 3 per cent. The impact of the overall degree of wage inequality existing, though sizeable, does not affect in any significant way, the gender wage gap, as shown by the low value of the "U" effect.

\section{[Table 9 about here]}

The previous analysis has shown that women are potentially more productive than men. Figure 2 is a bar chart representing the impact of groups of characteristics on the gender pay gap as based on JMP decomposition. The results clearly show that women have characteristics superior to men in terms of their impact on productivity along almost all dimensions.

The dimensions in favour of men are as follows. On average, women have less work experience, due to maternity interruptions. However, the impact on wage differentials would be about 2 per cent. In addition, women work slightly less hours, due to their lower work effort; they use less effective search methods and are more likely to migrate. All the other characteristics of women reduce the gap. Their greater educational endowment outweighs all other factors. If women and men had the same returns to education, women would have about 12 per cent higher wages. Moreover, due to their greater tendency to migrate, women work more often than men in urban areas, where wages are higher. Furthermore, on average, women are employed in better paid sectors and are less likely to work in the informal sector. Previous analysis has shown the greater job stability of women, as measured by their higher share of contracts in general, and permanent contracts, in particular.

\section{[Figure 2 about here]}

\section{Summary remarks and policy implications}

This paper has attempted to quantify the gender gap in early career in Mongolia. Unconditional wages of young men and women are not different. Nonetheless, once controlling for the typical productivity characteristics, including human capital, a gender wage gap of between 25 and over 30\% emerges. The gap, 
which is not statistically significant among young teenagers, becomes sizeable among young adults, in concomitance with the decision to marry and give birth, and remains stable up to the age of thirty.

JMP decomposition confirms that if wages were paid equally, women should have $11.7 \%$ more, even if only considering their higher educational attainment. Taking into account all the different characteristics of men and women, it appears that women should have, on average, 22 per cent more, a substantial gap, considering the low earnings of Mongolians.

The above analysis provides evidence supporting the hypothesis that employers pay lower wages to women than men with the same characteristics. This is not only unfair, but also inefficient, inasmuch as it not only reduces the overall productivity of the country, by discouraging the effort of women, but might also reduce employment and participation rates of the least motivated women. In addition, the most motivated women may decide to pursue their careers, postpone marriage and children, and thereby reduce the fertility rate in a country where the population is small and ageing.

Implementing an equal pay policy, one of the Millennium Development Goals, should be an important policy objective. It requires strengthening the legal framework and providing legal assistance to women reporting discrimination practices. Local authorities could provide this assistance and have an important effect on local communities. In addition, action should be taken to help women overcome barriers to better jobs and career prospects; for example, obliging firms to employ women in management roles. This type of positive action would be an important psychological and social factor and affect female labour market behaviour in the long term. The government should, of course, maintain childcare facilities and employers should guarantee fully-paid maternity leave. The role of tripartite agreements is very important to effectively implement equal pay policies. 


\section{References}

Darii, A.; Suruga, T. 2006. Economic returns to schooling in transition: A case of Mongolia, Kobe University, GSICS working papers, September, No. 9.

del Rosario, M. (2005), The Mongolian drop out study, Mongolian Education Alliance, Ulaanbaatar.

Filippin, A. and A. Ichino. 2005. "Gender Wage Gap in Expectations and Realisations", in Labour Economics, Vol. 12, No. 1, pp. 125-145.

Juhn, C.; Murphy, K.M.; Pierce, B. 1993. “Wage inequality and the rise in returns to skill”, in The Journal of Political Economy, Vol. 101, No. 3, pp. 410-442.

Halvorsen, R.; Palmquist, R. 1980., "The interpretation of dummy variables in semilogarithimic equations", in American Economic Review, Vol. 70, No. 3, pp. 474-75.

Kunze, A. 2003. "Gender Differences in Entry Wages and Early Career Wages”, in Annales d'économie et de statistique, No. 71/72, pp. 245-265.

Kunze, A. 2005. “The Evolution of the Gender Wage Gap”, in Labour Economics, Vol. 12, No. 1, pp. 73-97.

Malysheva, M.; Verashchagina, A. 2008. "The Transition from a planned to a market economy: How are women faring?" in F. Bettio; A. Verashchagina (eds): Frontiers in the Economics of Gender (Routledge, London).

Manning, A. and J. Swaffield. 2008. “The Gender Gap in Early-Career Wage Growth”, The Economic Journal, Vol. 118, No. 530, pp. 893-1024.

Morris E.; Bruun, O. 2005. Promoting employment opportunities in rural Mongolia, ILO, Bangkok.

Overseas Development Institute (ODI). 2008. "Gender and the MDGs. A Gender Lens is Vital for Pro-Poor Results”, Briefing Paper, N. 42, September.

Pastore, F. 2006. “The Gender Wage Gap among Young Adults in Italy. The Case of Campania and Veneto”, Seconda Università di Napoli, Typescript.

Pastore, F.; Verashchagina, A. 2007. When does transition increase the gender wage gap? An application to Belarus, IZA discussion paper, n. 2796.

Psacharopoulos, G. 1994. "Returns to investment in education: a global update”, in World Development, Vol. 22, No. 9, pp. 1325-1343.

United Nation Development Fund for Women (UNIFEM). Making the MDGs Work for All. Bangkok.

United Nations Development Programme (UNDP). 2003. Millennium Development Goals. National Reports. A Look through Gender Lens, United Nations Plaza, New York.

United Nations Development Programme (UNDP). 2006. Human Development Report. Oxford, Oxford University Press. 


\section{Appendix of Tables and Figures}

Table 1. Educational attainment by gender and age group

\begin{tabular}{|c|c|c|c|c|c|c|c|c|c|c|c|}
\hline & \multicolumn{3}{|l|}{$15-29$} & \multicolumn{3}{|l|}{$25-29$} & \multicolumn{3}{|l|}{$15-24$} & \multirow{2}{*}{$\frac{15-19}{\text { Total }}$} & $20-24$ \\
\hline & Male & Female & Total & Male & Female & Total & Male & Female & Total & & Total \\
\hline Uneducated & 4.64 & 2.06 & 3.34 & 3.46 & 1.94 & 2.65 & 8.05 & 4.88 & 6.43 & 3.07 & 4.29 \\
\hline Primary & 14.11 & 9.98 & 12.02 & 16.05 & 7.34 & 11.40 & 38.98 & 22.36 & 30.50 & 13.18 & 11.01 \\
\hline Basic & 33.94 & 31.53 & 32.72 & 22.96 & 18.12 & 20.38 & 41.10 & 35.77 & 38.38 & 54.29 & 14.7 \\
\hline Secondary & 31.77 & 34.98 & 33.39 & 24.32 & 31.07 & 27.92 & 7.63 & 27.24 & 17.63 & 27.52 & 45.94 \\
\hline Vocational technical & 3.63 & 3.23 & 3.43 & 5.80 & 5.07 & 5.41 & 0.85 & 3.66 & 2.28 & 1.24 & 4.63 \\
\hline Diploma, specialized & 1.83 & 2.71 & 2.28 & 4.20 & 5.61 & 4.95 & 0.85 & 2.03 & 1.45 & 0.15 & 2.79 \\
\hline Tertiary/bachelor & 9.79 & 15.06 & 12.46 & 22.22 & 29.45 & 26.08 & 2.54 & 4.07 & 3.32 & 0.56 & 16.49 \\
\hline Masters degree & 0.28 & 0.46 & 0.37 & 0.99 & 1.40 & 1.21 & - & - & - & - & 0.15 \\
\hline $\begin{array}{l}\text { Number of } \\
\text { observations }\end{array}$ & 3167 & 73248 & 6415 & 810 & 927 & 1737 & 236 & 246 & 482 & 2671 & 2007 \\
\hline
\end{tabular}

Table 2. Distribution of the population by labour market status

\begin{tabular}{|c|c|c|c|c|c|c|c|c|c|c|}
\hline & All & Men & Women & $15-19$ & $20-24$ & $25-29$ & Ulaanbaatar & $\begin{array}{l}\text { Aimag } \\
\text { centre }\end{array}$ & $\begin{array}{l}\text { Soum } \\
\text { centre }\end{array}$ & $\begin{array}{l}\text { Rural } \\
\text { area }\end{array}$ \\
\hline In school & 41.7 & 40.2 & 43.1 & 78.4 & 25.2 & 4.4 & 55.08 & 48.52 & 37.74 & 17.89 \\
\hline Engaged in home duties & 7.7 & 5.5 & 9.9 & 4.2 & 9.0 & 11.7 & 6.70 & 6.01 & 7.66 & 10.77 \\
\hline Took care of family members & 2.0 & 0.6 & 3.5 & 0.3 & 2.8 & 3.9 & 2.37 & 2.22 & 1.88 & 1.52 \\
\hline Self-employed & 6.5 & 10.5 & 2.7 & 0.7 & 7.5 & 14.3 & 3.76 & 3.60 & 5.08 & 14.78 \\
\hline Unpaid family worker & 10.9 & 9.8 & 11.9 & 5.7 & 14.9 & 14.2 & 0.61 & 1.66 & 3.97 & 41.92 \\
\hline Wage employment & 15.5 & 15.8 & 15.2 & 2.1 & 19.1 & 31.8 & 17.39 & 19.69 & 20.06 & 4.49 \\
\hline Part-time work & 0.4 & 0.4 & 0.4 & 0.1 & 0.7 & 0.6 & 0.41 & 0.28 & 0.56 & 0.35 \\
\hline Temporarily absent from work & 0.3 & 0.3 & 0.3 & 0.1 & 0.2 & 0.8 & 0.12 & 0.92 & 0.14 & 0.21 \\
\hline On sick leave or leave of absence & 1.0 & 1.3 & 0.7 & 0.6 & 1.2 & 1.4 & 1.14 & 1.02 & 1.11 & 0.62 \\
\hline Unemployed & 14.0 & 15.7 & 12.4 & 8.0 & 19.6 & 16.8 & 12.41 & 16.08 & 21.8 & 7.46 \\
\hline Number of observations & 6415 & 3167 & 3248 & 2671 & 2007 & 1737 & 2449 & 1082 & 1436 & 1448 \\
\hline \multicolumn{11}{|c|}{ Source: Own elaboration based on SWTS database, NSO Mongolia. } \\
\hline
\end{tabular}


Table 3. Sectoral composition of employment by gender and age group

\begin{tabular}{l|rrrrrr}
\hline & \multicolumn{1}{|c}{ All } & \multicolumn{1}{c}{ Men } & Women Young teenagers Young adults Oldest segment \\
\hline Agriculture & 0.73 & 0.93 & 0.49 & 0.87 & 0.23 & 1.09 \\
Livestock & 40.6 & 43.29 & 37.48 & 68.26 & 41.76 & 33.91 \\
Forestry & 0.68 & 0.85 & 0.49 & 1.3 & 0.7 & 0.55 \\
Fishery & 0.18 & 0.25 & 0.1 & 0.43 & 0.12 & 0.18 \\
Mining and Quarrying & 2.74 & 3.82 & 1.48 & 3.48 & 3.36 & 2.09 \\
Manufacturing & 3.88 & 3.14 & 4.73 & 2.61 & 3.6 & 4.36 \\
Electricity, Gas and Water supply & 1.96 & 2.89 & 0.89 & 1.3 & 1.39 & 2.55 \\
Construction & 2.92 & 4.33 & 1.28 & 2.17 & 3.25 & 2.82 \\
Wholesale and Retail Trade and househo & 7.62 & 5.77 & 9.76 & 5.22 & 6.73 & 8.82 \\
Hotels and Restaurants & 3.51 & 1.44 & 5.92 & 6.09 & 4.52 & 2.18 \\
Transport and storage & 3.92 & 6.03 & 1.48 & 1.74 & 3.48 & 4.73 \\
Tourism & 0.82 & 0.85 & 0.79 & 0 & 0.81 & 1 \\
Telecommunication & 0.87 & 0.51 & 1.28 & 0 & 0.35 & 1.45 \\
Financial services & 3.28 & 2.72 & 3.94 & 0.43 & 3.13 & 4 \\
Real estate, renting and business activities & 0.78 & 0.59 & 0.99 & 0 & 1.04 & 0.73 \\
Public Administration, Defence, compuls & 7.85 & 9 & 6.51 & 1.74 & 7.54 & 9.36 \\
Education & 8.44 & 4.67 & 12.82 & 0 & 7.77 & 10.73 \\
Health and social security & 2.19 & 1.44 & 3.06 & 0.43 & 2.67 & 2.18 \\
Community, social and personal services & 5.06 & 5.09 & 5.03 & 2.61 & 5.45 & 5.27 \\
Other & 1.96 & 2.38 & 1.48 & 230 & 862 & 2.3 \\
Total & 2,192 & 1,178 & 1,014 & & 2.100 \\
\hline Source: & & & & &
\end{tabular}

Source: own elaboration on SWTS of Mongolia, ILO. 
Table 4. Composition of wage employment by type of contract

\begin{tabular}{|c|c|c|c|c|c|c|}
\hline & & \multirow{3}{*}{ Total (\%) } & \multicolumn{4}{|c|}{ Of which } \\
\hline & & & \multirow{2}{*}{$\begin{array}{c}\text { Without } \\
\text { contract (\%) }\end{array}$} & \multicolumn{3}{|c|}{ With contract } \\
\hline & & & & Total (\%) & Written (\%) & Oral (\%) \\
\hline A & $\mathrm{B}$ & 1 & 2 & 3 & 4 & 5 \\
\hline $15-19$ & 23 & 10.5 & 15.6 & 3.0 & 2.8 & 10.3 \\
\hline $20-24$ & 24 & 39.3 & 39.9 & 38.4 & 38.1 & 48.3 \\
\hline $25-29$ & 25 & 50.2 & 44.5 & 58.5 & 59.1 & 41.4 \\
\hline Total & 26 & 100.0 & 100.0 & 100.0 & 100.0 & 100.0 \\
\hline Male & 27 & 53.7 & 57.6 & 48.1 & 48.1 & 48.3 \\
\hline Female & 28 & 46.3 & 42.4 & 51.9 & 51.9 & 51.7 \\
\hline Total & 29 & 100.0 & 100.0 & 100.0 & 100.0 & 100.0 \\
\hline Urban & 30 & 38.8 & 21.3 & 64.5 & 64.7 & 58.6 \\
\hline Rural & 31 & 61.2 & 78.7 & 35.5 & 35.3 & 41.4 \\
\hline Total & 32 & 100.0 & 100.0 & 100.0 & 100.0 & 100.0 \\
\hline West region & 33 & 19.5 & 26.6 & 9.1 & 9.1 & 10.3 \\
\hline Khangai region & 34 & 25.8 & 29.9 & 19.8 & 19.9 & 17.2 \\
\hline Central region & 35 & 18.1 & 15.4 & 21.9 & 22.2 & 13.8 \\
\hline East region & 36 & 11.4 & 13.7 & 7.9 & 7.7 & 13.8 \\
\hline Ulaanbaatar region & 37 & 25.3 & 14.4 & 41.3 & 41.2 & 44.8 \\
\hline Total employees /thous/ & 38 & 276.4 & 164.2 & 112.2 & 108.6 & 3.7 \\
\hline
\end{tabular}

Source: own elaboration on SWTS of Mongolia, ILO. 
Table 5. Unemployed youth by time to find a job, sex and age group

\begin{tabular}{|c|c|c|c|c|c|c|c|c|c|}
\hline & & \multirow{2}{*}{$\begin{array}{l}\text { Unemployed youth } \\
\text { /thous/ }\end{array}$} & \multicolumn{7}{|c|}{ Out of which: time to seek a job /per cent/ } \\
\hline & & & $\begin{array}{c}\text { Less than a week } \\
(\%)\end{array}$ & $\begin{array}{l}\text { 1-4 weeks } \\
\text { (\%) }\end{array}$ & $\begin{array}{c}\text { 1-2 months } \\
\text { (\%) }\end{array}$ & $\begin{array}{l}\text { 3-6 months } \\
\text { (\%) }\end{array}$ & $\begin{array}{l}\text { 7-11 months } \\
(\&)\end{array}$ & $\begin{array}{c}12-24 \text { months } \\
(\%)\end{array}$ & $\begin{array}{l}\text { More than } 24 \\
\text { months (\%) }\end{array}$ \\
\hline A & B & 1 & 3 & 4 & 5 & 6 & 7 & 8 & 9 \\
\hline Total & 1 & 45,1 & 2,8 & 5,9 & 13,4 & 20,1 & 9,2 & 25,7 & 22,9 \\
\hline $15-19$ & 2 & 8,7 & 2,9 & 7,2 & 18,8 & 26,1 & 10,1 & 29,0 & 5,8 \\
\hline $20-24$ & 3 & 21,0 & 3,0 & 6,0 & 15,0 & 22,2 & 7,2 & 26,3 & 20,4 \\
\hline $25-29$ & 4 & 15,4 & 2,5 & 4,9 & 8,2 & 13,9 & 11,5 & 23,0 & 36,1 \\
\hline Male & 5 & 25,6 & 4,4 & 7,4 & 12,3 & 19,7 & 9,9 & 24,6 & 21,7 \\
\hline 15-19 & 6 & 5,5 & 4,5 & 6,8 & 20,5 & 22,7 & 11,4 & 27,3 & 6,8 \\
\hline $20-24$ & 7 & 12,4 & 5,1 & 8,2 & 13,3 & 22,4 & 8,2 & 23,5 & 19,4 \\
\hline $25-29$ & 8 & 7,7 & 3,3 & 6,6 & 4,9 & 13,1 & 11,5 & 24,6 & 36,1 \\
\hline Female & 9 & 19,5 & 0,6 & 3,9 & 14,8 & 20,6 & 8,4 & 27,1 & 24,5 \\
\hline 15-19 & 10 & 3,2 & - & 8,0 & 16,0 & 32,0 & 8,0 & 32,0 & 4,0 \\
\hline $20-24$ & 11 & 8,7 & - & 2,9 & 17,4 & 21,7 & 5,8 & 30,4 & 21,7 \\
\hline $25-29$ & 12 & 7,7 & 1,6 & 3,3 & 11,5 & 14,8 & 11,5 & 21,3 & 36,1 \\
\hline
\end{tabular}

Table 6. Unemployment duration by gender and people with children

\begin{tabular}{l|rrr}
\hline & Men & Women Total \\
\hline Less than a week & 1 & 0 & 1 \\
& 2.08 & 0 & 0.91 \\
1-4 weeks & 6 & 2 & 8 \\
1-2 months & 12.5 & 3.23 & 7.27 \\
& 5 & 7 & 12 \\
3-6 months & 10.42 & 11.29 & 10.91 \\
& 10 & 8 & 18 \\
7-11 months & 20.83 & 12.9 & 16.36 \\
12 - 24 months & 4 & 5 & 9 \\
& 8.33 & 8.06 & 8.18 \\
More than 24 months & 11 & 20 & 31 \\
& 22.92 & 32.26 & 28.18 \\
Number of observations & 11 & 20 & 31 \\
Source: own elaboration on SWTS of Mongolia, ILO. & 22.92 & 32.26 & 28.18 \\
& 48 & 62 & 110 \\
\hline
\end{tabular}


Table 7. Unconditional gender wage gap by age in extended earnings equations

\begin{tabular}{|c|c|c|c|c|c|}
\hline Dep. variable & Control variables & All & $\begin{array}{l}\text { Young } \\
\text { teenagers }\end{array}$ & $\begin{array}{l}\text { Young } \\
\text { Adults }\end{array}$ & $\begin{array}{c}\text { Oldest } \\
\text { segment }\end{array}$ \\
\hline Monthly wages & Constant & -0.018 & 0.103 & -0.023 & -0.082 \\
\hline Monthly wages & Constant, Log hours & -0.036 & 0.115 & -0.071 & -0.089 \\
\hline Hourly wages & Constant & -0.0549 & 0.119 & 0.034 & 0.010 \\
\hline Monthly wages & $\begin{array}{l}\text { Constant, log hours, educational qualification } \\
\text { and work experience }\end{array}$ & $-0.282^{* * *}$ & -0.057 & $-0.307^{* * *}$ & $-0.298^{* * *}$ \\
\hline Monthly wages & $\begin{array}{l}\text { Constant, log hours, years of education and work } \\
\text { experience }\end{array}$ & $-0.274^{* * *}$ & -0.032 & $-0.296^{* * *}$ & $-0.299^{* * *}$ \\
\hline Hourly wages & $\begin{array}{l}\text { Constant, educational qualification and work } \\
\text { experience }\end{array}$ & $-0.223^{* * *}$ & -0.073 & $-0.249^{* * *}$ & $-0.229^{* * *}$ \\
\hline Hourly wages & $\begin{array}{l}\text { Constant, years of education and work } \\
\text { experience }\end{array}$ & $-0.214^{* * *}$ & 0.023 & $-0.233^{* * *}$ & $-0.228^{* * *}$ \\
\hline
\end{tabular}

Table 8. Augmented earnings equations by gender and age group

\begin{tabular}{|c|c|c|c|c|c|c|}
\hline Variable & All & $\begin{array}{c}\text { Young } \\
\text { teenagers } \\
(15-19) \\
\end{array}$ & $\begin{array}{l}\text { Young } \\
\text { Adults } \\
\text { (20-24) }\end{array}$ & $\begin{array}{l}\text { Oldest segment } \\
\quad(25-29)\end{array}$ & Men & Women \\
\hline Log of weekly hours & 0.0959 & 0.2413 & -0.1245 & $0.1752 *$ & 0.0999 & 0.1334 \\
\hline $\begin{array}{l}\text { Work experience from } 1 \text { to } \\
4 \text { years }\end{array}$ & 0.0767 & 0.1971 & -0.0570 & $0.2502 * * *$ & 0.1199 & 0.0519 \\
\hline We 5plus & $0.2210 * * *$ & 0.1196 & 0.0286 & $0.3950 * * *$ & $0.1942 *$ & $0.2359 *$ \\
\hline Women & $-0.2226 * * *$ & -0.0466 & $-0.1961^{*}$ & $-0.2110 * * *$ & - & - \\
\hline Secondary & $0.1412^{*}$ & 0.2004 & 0.1998 & 0.0772 & 0.1107 & $0.2068 *$ \\
\hline Voctecsec & $0.1627 *$ & 0.1092 & 0.2179 & 0.1270 & 0.0162 & $0.3290 * *$ \\
\hline Specsec & $0.4941 * *$ & 0.5191 & $0.6052^{* *}$ & 0.3642 & $0.4228 *$ & $0.5577 * *$ \\
\hline Tertiary & $0.6164^{* * *}$ & - & $0.7041^{* * *}$ & $0.4738 * * *$ & $0.6325^{* * *}$ & $0.5603^{* * *}$ \\
\hline Master & $0.6836^{* * *}$ & - & 0.6382 & $0.6329 * * *$ & $0.5060 *$ & 0.5191 \\
\hline Studywork & -0.0752 & 0.2461 & -0.0421 & -0.0774 & -0.0730 & -0.0625 \\
\hline Fixed-term contract & $0.2648^{* * *}$ & $0.2787^{*}$ & $0.2251^{*}$ & $0.2393 * *$ & $0.3268 * * *$ & $0.2210^{* *}$ \\
\hline Permanent contract & $0.1720 * *$ & $0.4724 * *$ & 0.1176 & 0.1516 & 0.1931 & $0.2166^{* *}$ \\
\hline Married & $0.1272 * *$ & 0.3797 & 0.0192 & $0.1309 *$ & $0.1772 * *$ & 0.0160 \\
\hline Livetog & $0.3452 * *$ & 0.0000 & $0.7496 * *$ & 0.2105 & $0.3874 *$ & 0.1999 \\
\hline Divsepwid & 0.0028 & 0.0000 & $-0.6728 *$ & 0.0827 & 0.2986 & -0.1125 \\
\hline Loneparent & 0.0235 & -0.2032 & -0.2127 & 0.1204 & -0.0613 & -0.0003 \\
\hline Immwithfam & -0.0917 & 0.0199 & -0.1999 & -0.0736 & $-0.2046 * *$ & 0.1421 \\
\hline Immeduc & -0.1012 & 0.1794 & -0.2977 & 0.1331 & -0.5491 & $0.4294 *$ \\
\hline Immjob & -0.0107 & 0.1139 & -0.1509 & 0.0334 & -0.0342 & 0.0040 \\
\hline immlooking & 0.0468 & $-2.4586 * * *$ & 0.1742 & 0.0605 & 0.1692 & -0.1483 \\
\hline Union member & -0.0689 & 0.3985 & -0.1579 & -0.0511 & -0.1010 & -0.1062 \\
\hline train1 & -0.0673 & -0.7542 & -0.0862 & -0.0447 & -0.1447 & -0.0027 \\
\hline train14 & -0.0262 & 0.1615 & -0.0307 & -0.0108 & 0.0929 & 0.0157 \\
\hline train58 & $-0.1845^{*}$ & 0.0000 & -0.1817 & $-0.1747^{*}$ & $-0.2903^{*}$ & -0.2608 \\
\hline Trainmore & -0.1406 & $-1.1949 *$ & -0.3972 & -0.0782 & -0.2559 & -0.1406 \\
\hline Informnet & $-0.1134 *$ & 0.0102 & -0.1004 & $-0.1706^{*}$ & $-0.1989 *$ & -0.0510 \\
\hline Empldirect & -0.0389 & 0.0371 & 0.0406 & -0.1316 & -0.0019 & -0.0540 \\
\hline Rural & $-0.3451 * * *$ & -0.2172 & $-0.3152 *$ & $-0.3517^{* *}$ & $-0.2487 * *$ & $-0.5506 * * *$ \\
\hline _cons & $3.3281 * * *$ & $2.4550 * * *$ & $4.3739 * * *$ & $2.8195^{* * *}$ & $3.2812 * * *$ & $2.9800 * * *$ \\
\hline N & 1852 & 165 & 717 & 970 & 1042 & 810 \\
\hline $\mathrm{Ll}$ & $-2.20 \mathrm{E}+03$ & $-1.00 \mathrm{E}+02$ & $-8.40 \mathrm{E}+02$ & $-1.10 \mathrm{E}+03$ & \#\#\#\#\#\#\# & -900.0000 \\
\hline
\end{tabular}




\begin{tabular}{l|llllll}
\hline Aic & $4.50 \mathrm{E}+03$ & 305.3669 & $1.80 \mathrm{E}+03$ & $2.40 \mathrm{E}+03$ & 2600.0000 & 1900.0000 \\
$\mathrm{R}^{2}$ & 0.38 & 0.60 & 0.41 & 0.38 & 0.40 & 0.46 \\
\hline
\end{tabular}

Note: Dependent variable is the natural log of declared monthly wages. ${ }^{*} p<0.05 ; * * p<0.01 ; * * * p<0.001$. Note: The years of education for each educational qualification are as follows: 0 for the uneducated; 4 for primary education; 8 for basic or incomplete secondary education; 10 for complete secondary education; 12 for vocational and technical secondary education; 13 for specialized technical secondary education; 17 for university degree; and, 19 for a master degree.

The estimates include controls for industry and place of residence.

Source: own elaboration on SWTS of Mongolia.

Table 9. Juhn, Murphy and Pierce (1993) decomposition of gender wage gap

\begin{tabular}{r|rrrr}
\hline & $T$ & $Q$ & $P$ & $U$ \\
\hline Mean & 0.0349739 & -0.200214 & 0.232058 & 0.0031298 \\
\hline
\end{tabular}

Note: $T$ = total gender wage gap; $Q=$ impact on the wage differential of individual characteristics; $P=$ impact on the wage differential of prices to individual characteristics; $U$ = impact on the wage differential of the residual wage distribution.

Source: own elaboration on SWTS of Mongolia, ILO. 
Figure 1. Hours worked per week by gender

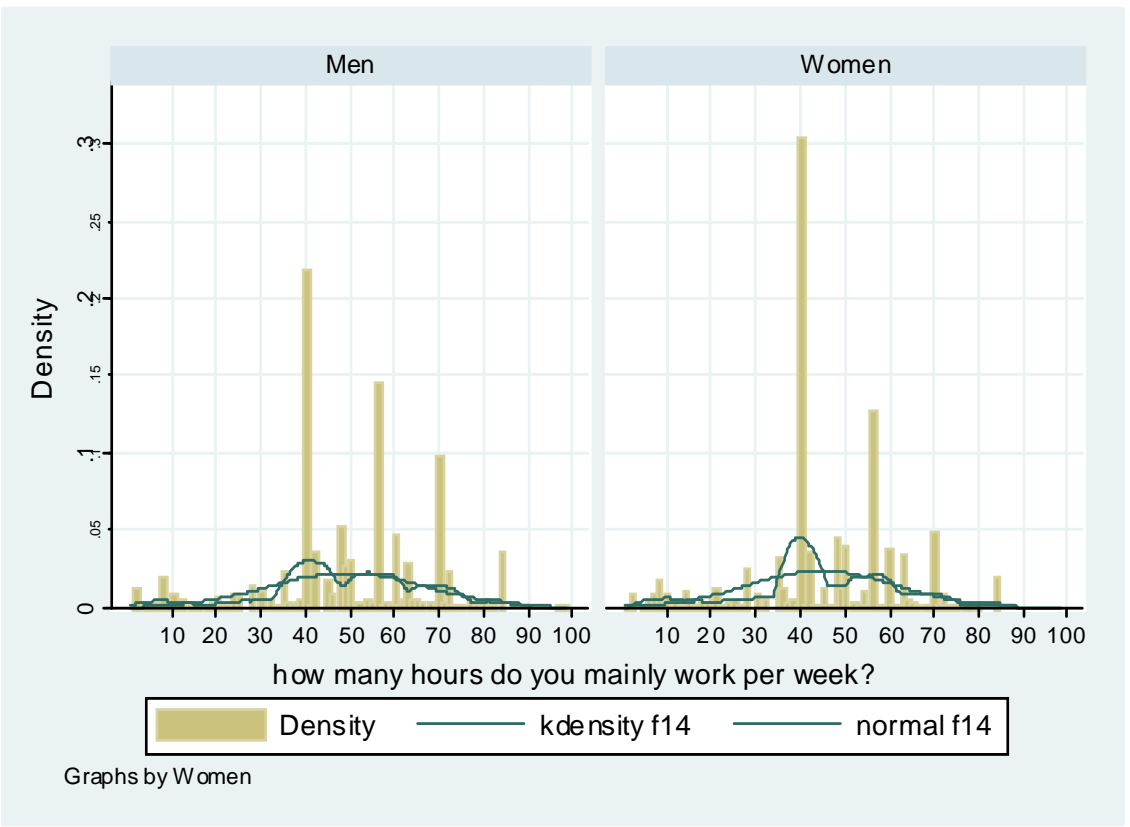

Source: own elaboration on SWTS of Mongolia, ILO.

Figure 2. Quantity effects on the gender pay gap based on JMP (1993)

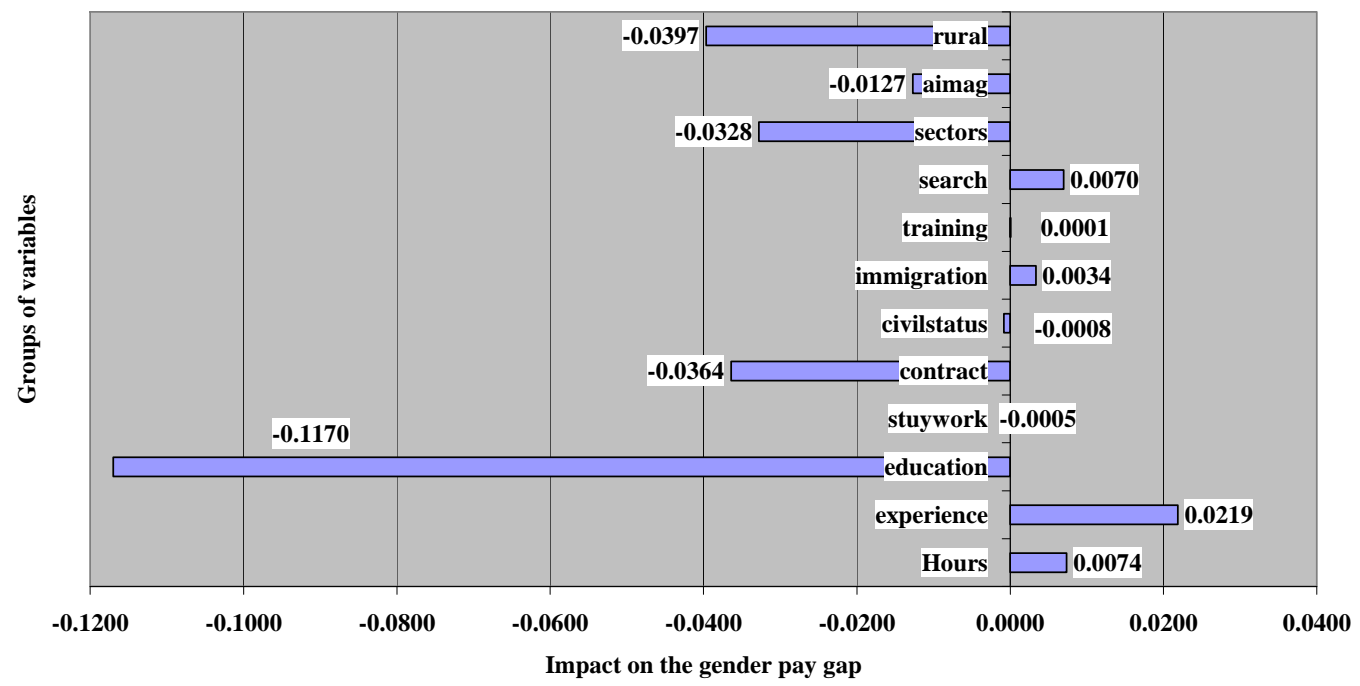

Source: own elaboration on SWTS of Mongolia, ILO. 